\title{
Global (Citizenship) Education as inclusive and diversity learning in Religious Education
}

\author{
Ralf Gaus $^{1} \mathbb{D}$
}

Accepted: 4 June 2021 / Published online: 14 June 2021

(c) The Author(s) 2021

\begin{abstract}
School education is no longer just the place where students are supposed to deal with local phenomena and issues, but also with global ones. Every subject in German schools, such as Religious Education, has to make its own contribution to the Global Education of students. The goals of interest and educational policy associated with this vary. As a result of the AGENDA 21 process, Global Education has been implemented in German curricula, as in many other countries. This article assumes that Religious Education achieves its goal precisely when it is designed to be inclusive and students experience the topics of human rights, dignity of the human person, and social justice in the classroom. For this to happen, diversity and difference must be valued and used as learning opportunities.
\end{abstract}

Keywords Global Citizenship Education · Religious education · Theology · Diversity learning · SDGs · Global competence

\section{Introduction}

Globalisation and digitalisation have affected all areas of life. New forms of (digital) communication, pandemics, ecological changes, migration movements, etc., they all have a global character. Today's societies are thus no longer confronted only with national phenomena, questions or problems, but also with global ones. Local and national perspectives are losing more and more importance and despite efforts to the contrary, societies can only be understood as "united nations" or as "world society" (Luhmann, 2019, p. 14). This raises questions about social justice, poverty, inequality and social exclusion in a global world. Both in terms of content and as an educational goal, human rights and values such as respect, diversity, tolerance and solidarity are associated with this.

In its AGENDA 2030 process of the UN, the Global (Citizenship) Education has an important function (see also UNESCO, 2015, 2020). It should help prepare (young) people for these global challenges, educate them to become responsible (world) citizens and thus contribute to peaceful, just, inclusive and sustainable societies. This concept of Global

Ralf Gaus

ralf.gaus@ksh-m.de

1 Department of Social Work and Religious Education, Katholische Stiftungshochschule, Munich, Germany 
(Citizenship) Education is "relatively new" in UNESCO policy (cf. Akkari \& Maleq, 2020, p. 4), even though there are corresponding precursors both politically and in terms of educational concepts. But with the signing of AGENDA 2030, Global (Citizenship) Education has found its way into many school curricula and is now also part for example of Religious Education (in Germany). Therefore, in the following we will consider how Global (Citizenship) Education, which demands among other things respect and recognition of diversity, can look like in Religious Education and what contribution RE makes.

\section{Global (Citizenship) Education for orientation in and to shape a (global) society}

Taking up global questions, topics and problems in education and thus giving people a global perspective is not new in education. This is because education as it was understood in European modernity and prepared, for example, by Comenius or Kant, is universalistic and cosmopolitan at its core. It is about crossing horizons, improving human living conditions on a global scale, and peace building based on the principle of respect for diversity. In contrast, however, there are two significant changes today. On the one hand, the current "discourse on GCE [Global (Citizenship) Education; R.G.] is mainly linked to the agendas of international organisations" (Akkari \& Maleq, 2020, p. 4); on the other hand, the global society is no longer just a vision. Rather, it can be seen as already realised. Instead of creating the global society, people are tasked with shaping it today.

The diversity with which people and societies are confronted today is a considerable challenge. Foreign cultures, (religious) world views and religions are coming closer together to a considerable extent due to global networking. Consequently, societies are becoming more diverse in their thinking, actions and self-understanding. And societies react differently depending upon how they understand themselves on a global level. According to the German Advisory Council on Global Change, modern societies and modern thinking are in a fundamental and epochal "transformation" and "transition" (2011). Social self-conceptions and thus social identity itself are evolving due to current social changes. Personal and societal values are being questioned and need to be reconsidered and changed.

In addition, the movement of people within or between countries, for example, also changes the individual understanding of a citizen. "Complex forms of citizenship have emerged at multiple levels (national, regional, municipal and local), as have new forms of belonging" (Organisation for Economic Co-operation and Development [OECD], 2020, p. 55; see also United Nations Educational, Scientific and Cultural Organization [UNESCO], 2015). As a result, communities need to redefine their identity and local culture, but also learn to act as part of the global society. This is particularly evident in ecological or pandemic crisis. These crises show that the global society is also a "world risk society" (Beck, 1999), because a global crisis is also a crisis of the whole humanity.

Currently, the United Nations, as an assembly of nation states, is attempting to find appropriate answers to these changes and challenges. Within the framework of AGENDA 2030 with its 17 Sustainable Development Goals (SDGs) (United Nations [UN], 2015) the United Nations formulates what it believes needs to be done to achieve the goal of a humane, peaceful and just global society. For this reason, the UN calls for "Global 
Citizenship Education" (UNESCO, 2015). In target 4.7 of the SDGs Global Citizenship Education is implemented.

"By 2030, ensure that all learners acquire the knowledge and skills needed to promote sustainable development, including, among others, through education for sustainable development and sustainable lifestyles, human rights, gender equality, promotion of a culture of peace and non-violence, global citizenship and appreciation of cultural diversity and of culture's contribution to sustainable development" (UN, 2015, target 4.7, p. 19).

Therefore, the AGENDA 21 signing countries have committed themselves to anchoring Education for Sustainable Development and Global Citizenship Education in the education curricula and to transform the learning environments to make them possible. In this way, students should be able to deal critically with issues and topics of environmental or social justice. Education should - according to the normative expectation-not only impart knowledge, but also contribute to a "change in people's attitudes" (UN, 1992, chpt. 36.3). Despite support for these SDG targets, there is also criticism from various sides. For example, Akkari and Maleq note that the goals are neither structured nor prioritised, so that they can hardly be implemented. Similarly, "concepts such as citizenship and human rights are interpreted differently according to the political, economic and cultural background" (2020, p. 5).

In this way, however, they also fail to achieve their goal of transforming the social system towards a high quality of life for all. For, as Huckle and Wals (2015) note, emerging tensions between economy, ecology and social issues are not addressed. Instead, "UNESCO has trimmed and tamed DESD [Decade of Education for Sustainable Development; R.G.] so that it does not challenge neoliberalism and fails to develop GESC [Global Education for sustainability citizenship; R.G.]" (2015, p. 497). For this reason, it is also understandable that different forms and goals of Global (Citizenship) Education are pursued worldwide (cf. Akkari \& Maleq, 2020, pp. 9-12). A critical examination of what Global (Citizenship) Education can and should achieve is therefore urgently needed.

This is also necessitated by the fact that the OECD also considers "global competence" and thus Global (Citizenship) Education to be essential. For this purpose they define Global Competence as.

"a multidimensional capacity that encompasses the ability to: (1) examine issues of local, global and cultural significance; (2) understand and appreciate the perspectives and worldviews of others; (3) engage in open, appropriate and effective interactions across cultures; and (4) take action for collective well-being and sustainable development" (OECD, 2020, p. 55).

This is in response to and in support of the 2030 Agenda for Sustainable Development and global change as a challenge for the future. Global competences should both enable better career prospects for students and contribute to the improvement of societal challenges (OECD, 2018, 2019, 2020). For this reason, the OECD surveyed young people's understanding of global issues and their attitudes towards cultural diversity and tolerance (OECD, 2019, 2020; Weis et al., 2020). 


\section{Religious Education and Global (Citizenship) Education}

Education for Sustainable Development and Global Citizenship Education is now anchored in all curricula in Germany (see also Schreiber \& Siege, 2016). In every compulsory school subject, including Religious Education, students are now supposed to deal with those phenomena, topics, questions and problems raised by globalisation. Religious Education is also faced with the task of offering Global (Citizenship) Education in the classroom as an interdisciplinary competence.

For many years, Religious Education in Germany has also addressed issues from a global perspective in the curricula. However, these topics are usually dealt with individually and less as a continuous perspective. In addition, for a long time in Religious Education as well as in religious pedagogy, political issues and the questions of social justice in society had lost importance compared to interreligious learning or approaches to respiritualization (Noormann, 2012, p. 195; Schweitzer, 2020, p. 273). This has changed significantly in recent years and, triggered by the anchoring in the curricula, there are also discussions between Global Education and Religious Education (Benk, 2019; Gaus, 2014, 2015, 2018).

In contrast to international discussions on whether or not Religious Education should be involved in Global Education (Abdullahi, 2015, p. 805), Annette Scheunpflug believes that, for the German context, "Global Education as well as Religious Education [...] are indispensable for a modern society" (2012, p. 230; see also Lang-Wojtasik, 2011). In doing so, Religious Education and Global (Citizenship) Education not only complement each other, but both can also learn and benefit from each other! On the one hand, Global (Citizenship) Education addresses issues of power and resources and thus also helps Religious Education to reflect self-critically. On the other hand, Religious Education can contribute to dealing with religious heterogeneity and complexity, as well as contribute its own Christian perspective on a global world society. For Religious Education as a whole, but especially in Global (Citizenship) Education, it is not only about the question of whether students are well positioned in the labour market. The Christian message lives from, and for the vision of a peaceful, inclusive and just world (society). All people should participate in it equally and live peacefully together. Not respecting people or excluding them is not only unjust, it is also against God. In the Judeo-Christian tradition, faith and justice are so closely linked that injustice is not only socially wrong but is also directed against God (see also Grümme, 2016, pp. 202-203). Therefore, according to Andreas Benk, Jesus' themes are "not death and resurrection, but concrete human hardship and the hope of overcoming it through God's intervention here and now. In view of this 'great transformation' expected by Jesus, he called for conversion, that is, participating in the building of a truly human world" (2019, p. 214). In words and deeds, Jesus ensured that people became part of the community again, and he integrated them so that a peaceful and inclusive society emerged. This value is similarly reflected in Pope Francis' proclamation Evangelii gaudium (Francis, 2013, 2015, 2020). In it he says: "The Gospel is about the kingdom of God (cf. Lk 4:43); it is about loving God who reigns in our world. To the extent that he reigns within us, the life of society will be a setting for universal fraternity, justice, peace and dignity" (Francis, 2013, Sect. 180). Therefore, Christians are to overcome differences among people in terms of origin, nationality, colour or religion (see also Francis, 2020). 
And also the conciliar process of the World Council of Churches with its theology of the oikos (WCC, 2018) is based on a global justice perspective. Since the sixth assembly of the World Council of Churches in Vancouver in 1983, this global justice perspective has been linked to peace, justice and the integrity of creation. According to this, all people are called upon to work together responsibly, socially and sustainably for the one world.

\section{Some aspects and challenges for Global (Citizenship) Education}

However, the implementation of Global (Citizenship) Education in the curricula is strongly dependent on the national context, as already described above. Besides national ideas, definitions of justice or ideas of citizenship, both historical and contemporary factors play a role. Furthermore, didactical considerations also play an important role. After all, if the goal of Global (Citizenship) Education is to shape a humane and just world society and to empower people to work for and participate in it, then it requires not only knowledge but also one's own motivation. In most cases, Global Learning topics have so far been treated cognitively in class through texts and films. However, it is questionable whether this approach is successful and whether it does justice to the topic.

Taking the attitudes of young Germans as an example, a few aspects can be outlined for further considerations, without claiming to have answered the topic completely. In the general self-description, younger people between the ages of 12 and 25 today are more open and tolerant towards other social groups, cultures, religions and ways of life than they were a few years ago (cf. Albert et al., 2019, p. 18). Looking at the results of the PISA study, there is also corresponding knowledge about other people. For example, German pupils aged fifteen state that they are well informed about global and intercultural problems. They show respect for people from other cultures and are confident in solving tasks on global issues. "However, the self-assessments also show that their concrete interest in learning about other cultures as well as their willingness to actively work for global goals is rather low in international comparison" (Weis et al., 2020 , p. 6). The students thus perform well above all in the cognitive areas, but not in implementation, for which emotions, subjective norms and motivation are important. There is thus a gap between students' knowledge and awareness and their own actions ("mind-behaviour-gap").

Knowledge for its own is thus not enough for change, as Yendell (2017) can show, for example, in the context of religious tolerance among young people in Europe. Besides knowledge, direct contact with other people is also necessary to overcome stereotypes. At the same time, not every form of relationship and contact is positive.
"The degree of stereotyping depends on both the type of relationship (e. g. contact with colleagues, acquaintances, friends or relatives) and the quality of the contact. Certain conditions such as equal status, cooperative activity, continuity and meet- ing in person may improve interpersonal attitudes between in- and outgroups" (2017, p. 275).

For the implementation of the Global (Citizenship) Education this means:

1. Young people need knowledge about other people, other world views, attitudes, etc. In the process, they must also learn to assess values such as tolerance, diversity, etc. as 
relevant for them. However, knowledge does not necessarily lead to action. Knowledge can also lead to different forms of action.

2. Therefore, there is a need for places where young people meet other people and come in contact with each other. Direct contact leads to a confrontation with the "otherness" of the other. The personal and social encounter has a concrete influence on the values and attitudes of young people.

3. In order to learn values and attitudes such as tolerance or diversity, places are needed where these values can be lived and experienced. For this, external, structural conditions must be created that can serve as "living" examples for young people, such as kindergartens or schools.

Therefore, Lang-Wojtasik requests that Global (Citizenship) Education has to be constructed as a fundamentally social inclusive didactic approach (2018), where difference and diversity in the classroom and teaching should be perceived, valued and embraced as a learning occasion and opportunity. In this way, schools or Religious Education, for example, would open up learning spaces in which the themes of a just, peaceful, solidary and humane global society and social justice can be experienced, reflected upon and shaped (with and through classmates), thus making a first contribution to a humane global society. Therefore, a perspective on the (religious, cultural...) diversity within the class or its thematization should take place and should be part in the curriculum. This is important for two reasons in particular. On the one hand, the classroom is the first place of learning where experiences with others can be made. On the other hand, especially with these topics, content and educational processes must be congruent. Human rights, for example, can only be adequately taught and learned if the conditions for the learning group and within the learning group are humane and just.

\section{Global (Citizenship) Education as inclusive and diversity learning}

Global (Citizenship) Education, now understood as inclusive learning, recognises and addresses diversity. In doing so, social inclusion combines themes and contact opportunities by creating structural learning conditions. Social inclusion is both a necessary condition and a goal of Global (Citizenship) Education and a (global) society. Social inclusion and the recognition of diversity combine social justice and social, cultural and political participation. The basis for school education to value diversity and difference as well as be inclusive stems primarily from human dignity and human rights. The Universal Declaration of Human Rights (UN, 1948) in particular can be seen as the realization of the global society. For, according to it, all people are granted equal dignity and rights, regardless of their legal status in relation to the country in which they are currently residing. Both human dignity and human rights are unconditional. Thus, people do not have to fulfil any conditions in order to be recognized as human beings. But this also means that similarity is not a prerequisite for basic rights, just as diversity would not be a reason for exclusion. Human dignity and human rights are the core of an open (world) society. This allows that people could be different in what they think, live or believe. Human rights emphasize both individual diversity and normative equality.

On the basis of this unquestionable human dignity, the Catholic Church and the United Nations both consider, that every human being has the right to education, regardless of gender, age, race, ethnicity, stage of development, the respective cultural conditions, sexual 
orientation, socio-economic status, physical abilities, religious beliefs or political beliefs. Every person must be given the opportunity to fulfil their basic right to social, economic, and political participation. At the same time, however, all people should be enabled to enter into dialogue in a tolerant and respectful manner in order to promote unity, solidarity and peace (see also Siebenrock, 2009, p. 567; UN, 2015, chpt. 25; Vatican Council \& Paul VI., 1965, chpt. 1.1).

Thus, every person has the right to a unique individuality, to recognition and also the right to participate equally in the political, social and cultural life of the community. This marks an important mediating factor of a school. People are searching for orientation both in the world with other people and in society with its values, norms and roles. Schools have the task of providing this orientation and knowledge, values and roles. They should ensure that people can orient themselves both in the diverse world and diverse society in which people live. Therefore, the school as an institution has the task of teaching people and enabling them to connect to a (global) society.

Education, and schools in particular, therefore, have the fundamental task of including people, i.e. supporting and enabling them to participate in their social rights. It does this by creating the possibility of encounter and exchange as a space for interaction, or also by imparting the necessary knowledge. Therefore, schools and teachers always have to weigh up between equality and difference. On the one hand, schools and teachers have to integrate diverse people with their different life situations, topics, learning requirements, religions and world views etc. and give them equal opportunities. They have to include these different and diverse people in one learning group in order to educate them and bring them up to the same level of knowledge. A school, therefore, has to ensure equality and similarity among the students. On the other hand, however, the goal of education is always difference and diversity. For through education, every person should become him/herself and thus as unequal as everyone else.

Classes and study groups reflect the diversity of (world) society to a small extent. Some of them are as diverse as the society for which schools train people today. The variety in and outside the classroom will continue to increase. Societies and learning groups are becoming more diverse.

But difference and diversity often also mean exclusion. We must also acknowledge that exclusion does not mean that people are outside of society. Exclusion takes place within society. Even if people are excluded, they are still part of society (Kronauer, 2006, p. 29). They are only prevented from fully participating in the social, economic, and political life of the community. This happens mainly because people are actively prevented from doing so by more powerful groups by labelling them as "different" and thus not as "normal" or "belonging". Persons are thus actively prevented from exercising their rights. Exclusion is usually accompanied by ascriptions with the aim of stigmatising individuals. These can be ascriptions such as "migrant", "foreigner" or, with religious connotations in current European political or social discourse, "refugee as Muslim" (Pickel \& Pickel, 2019). But schools and teachers can also contribute to the exclusion of students through certain practices of action. For example, differences in terms of migration, gender or performance are actively created or reinforced within the school. This can be seen, for example, in gender-specific calling behaviour, or through statements by teachers on gender and ethnicity, or through mechanisms of institutional discrimination against children and young people from educationally disadvantaged families and with a migration background (see also Bohl, 2013, p. 244). 


\section{Global (Citizenship) Education as inclusive and diversity learning in Religious Education}

From a Global (Citizenship) Education perspective, classes and learning groups reflect the diversity of (global) society to some extent. Based on the human dignity of each individual, Religious Education has the task of enabling (young) people to have the right to participate equally in the political, social and cultural life of the community and thus contribute to a just world. Therefore, in general, educational institutions should, as formulated by the Congregation for Catholic Educational Institutions for Catholic Education in particular, understand diversity as an educational task and teach respect for it. Thus, based on the "respect for the dignity and uniqueness of the individual" (2014, Sect. 11), "diversity should not be denied", but must be "seen as an opportunity and a gift" (2014, Sect. 13). The different identity characteristics, such as age, gender, religion or national origin, are thus positive resources to be used accordingly for learning. It is this diversity that constitutes a person. Therefore, people must not be reduced to one of these characteristics. Their diversity must be treated positively in educational processes and be "enhanced" (2014, Sect. 13).

However, treating diversity positively in educational processes means more than just getting to know members of different cultures, for example, in order to reduce prejudices. Rather, (RE) teachers and learners alike must develop diversity competences. This includes not only respect, recognition and appreciation of diversity, but also reflection upon one's own values, attitudes and exclusion mechanisms, as well as negotiating common ground.

In Global (Citizenship) Education, a good connection could be made to the power-sensitive diversity approaches that emerged in the 1990s and have their foundation in the social movements and civil rights organisations of the United States from the 1950s to the 1970s. This is because they are not only pedagogically but also politically relevant (see also Walgenbach, 2014, pp. 97-112). Thus, these approaches are about an appreciative view of the diversity within the learning group and the multidimensionality of these differences. To this end, no lines of difference are drawn, such as between Catholics and Muslims, women and men, or nationals and foreigners. Nevertheless, these approaches know that there are "different identities, social affiliations and group characteristics" in society and that these are also "effective" in educational and training processes (Walgenbach, 2014, p. 93). The power-sensitive diversity approaches point out that social identities and affiliations are products of relations of domination and power, such as racism, anti-Semitism or ableism. That is why they are very interested in the intertwining of identity constructions and power relations and consider a critical reflection of social structures to be necessary.

For Religious Education this means that it can be the place where students can voice their experiences of exclusion, racism, poverty, etc. and where teachers can reflect with students on social structures that exist in the classroom, in the school and beyond. Acquiring diversity competence in Religious Education means reflecting with students from a religious perspective on issues of power, domination, race or culture, on social affiliations and group characteristics, and considering how social and cultural participation of all is possible in order to create peace and a just global society. In doing so, it can also be considered with the students how they can advocate socio-politically for appropriate institutional framework conditions, dismantling of barriers and participation of all. Without a political framework, the diversity approach runs the risk of becoming an ideology. According to Grümme, for where a diversity-sensitive (religious) pedagogy "assigns itself a dominant role, it overestimates its possibilities — and ends up being ideologically abusable itself, 
because it turns problems into pedagogical problems, which can ultimately only be solved politically" (2019, p. 137).

(Religious) Education must value diversity, but diversity approaches run the risk of becoming arbitrary if they do not reflect "diversity". This is because people are not different in themselves, but only with regard to a reference point (see also Walgenbach, 2014, pp. 12-14). Diversity and difference exist on the borderline of what is usually called "normal" (i.e. conforming to the norm) by individuals, societies or educational institutions. The question of difference and diversity thus also raises the "powerful" question of normality and the values and norms behind it (see also Lang-Wojtasik, 2018, p. 25). Religious Education must thereby self-reflexively consider in two respects which normative ideas and goals it is pursuing. Education cannot do without normative considerations (see below Grümme, 2019, pp. 135-136). Education needs goals and ideas of "normal" persons towards whom education wants to be directed. Without these goals and ideas, education prevents learning and development. Teachers cannot otherwise know when they need to help someone. At the same time, education is also blind to structural factors that prevent education and participation. However, differentiation categories are also necessary because otherwise inequality and exclusion would become entrenched and the diversity approach would become cynical. For not all differences between people are equal. It makes a difference whether they are individual, personal, cultural differences or structural and social inequalities. Highly gifted people and socially disadvantaged people cannot be weighed against each other as equal in the perspective of social justice (see also Trautmann \& Wischer, 2011, p. 66). So there are differences and differentiations that are necessary in the educational process because they enable opportunities and contribute to or hinder a global society.

But even these principles, norms and values that underlie these differentiations must not be seen as absolute. They, too, must be critically questioned again and again. For they too are historical and thus themselves subject to certain power factors and ideas of domination. According to Grümme, it is precisely here that Religious Education can bring in religions, denominations, religiosities or world views as a point of reference for the distinctions. In this way, religious convictions and traditions can be a positive resource that can be of importance for a just and solidary global society.

In general, religion must also be valued as a category of diversity, which is why Global (Citizenship) Education must deal with religion. Religious ideas, convictions and traditions are distinctive features of people and give them orientation in the world. Therefore, it is also important to deal with them and their messages in class and to ask what contribution they make to a just and solidary global society. In doing so, however, they must also be reflected upon self-critically. Religious convictions and traditions include and exclude people, and thus Religious Education also produces diversity and social exclusion through its content. Therefore, learners in Religious Education should be aware of both the positive effects of religion, e.g. as motivation for peace efforts, commitment to a just and peaceful global society, and the negative effects of religion, e.g. fundamentalism, motivation for conflicts. Especially in Religious Education, this can then also offer the learning occasion to reflect on one's own religious ideas and actions, for example, with the biblical message.

This would also be possible from the point of view of diversity in denominational Religious Education at schools. For, according to Wohlfart Schweiker, the dissolution of 
denominational Religious Education would be the "dissolution of diversity and difference in a homogenising Religious Education" (2012, p. 12).

In contrast, Religious Education must value the diversity within the learning group and the multidimensionality of these differences to contribute to interreligious understanding and religious tolerance. To do so, it must take up the diversity of ((inter)religious ...) perspectives of the students and use them as learning opportunities, which thus helps young people to cope in a plural and global world.

Therefore, Religious Education must then also be about reflecting with the pupils on these questions within the Catholic faith and on the relationship to other religions and world views or to other people as such. It must be a matter of facing up to plurality and not closing oneself off. ${ }^{1}$

\section{Diversity-sensitive Religious Education as Global Citizenship Education}

Taking diversity in the classroom as a learning occasion for Global Citizenship Education in Religious Education broadens the previous Religious Education perspective. It provides familiarity with the diversity of social, cultural and religious forms of expression. To this end, it breaks up the German, Eurocentric or Western perspective that is often unconsciously applied to topics and circumstances and, ultimately, also to people. In this way, it also makes it possible to be a "one-world church". For although we always speak of the "one-world church", we implicitly mean the European Western character. Instead, a diversity-sensitive Religious Education should sensitise young people to global contexts and injustices in which they live (their faith), as well as to the different ways of life, life plans and forms of lived faith. Basically, it is about an awareness that there are no longer only similarities and differences, e.g. between religions and religious ideas, societies or cultures, but also mutual influences and adoptions from the respective other. Thus, it helps to experience one's own position, from which religious learning takes place in the classroom, as perspective and as a form of lived faith. To this end, Religious Education familiarises people with this diversity and confronts them with it. The starting point is the classroom and people's world of experience. Religious Education looks for local and global forms and influences in people and tries, if possible, to create concrete opportunities for encounter. In the discussion, it then searches for commonalities, differences and homogenisations generated by the processes of globalisation. In this way, Religious Education connects local and global at the local place of learning, school. Thus the foreign is seen in the own and the own in the foreign becomes a learning process.

To this end, however, it does not only deal with religious ideas, but with the concrete people themselves; with their wishes, ideas and experiences and brings these into discussion with the wishes, ideas and experiences of the other young people in class. Religious Education is based on the recognition of the other as other, and demands and promotes this. It is about a basic attitude stemming from the Christian relationship with God, to recognise other people and cultures, not for strategic reasons, but to appreciate them in what they are for themselves and others. This is not about "usefulness" according to economic logic,

\footnotetext{
1 This can be observed, among other things, especially in Catholic schools worldwide, that for a certain part of parents the "relative socio-cultural homogeneity" is highly attractive when choosing Catholic schools (see also Gruehn \& Koinzer, 2019, p. 57; Maussen \& Bader, 2014).
} 
about specific strengths and abilities, but for the sake of the people themselves. In this way, young people enter a process in which they can experience how vulnerable people are and how similar and close and at the same time also strange and incomprehensible they remain to each other. It is precisely this strangeness that a diversity-sensitive Religious Education does not attempt to dissolve, but preserves it as a learning occasion and attitude (see also Meyer, 2015). To this end, the stereotypical images that prevail about certain persons, religions and cultures in society must also be addressed and critically questioned in Religious Education. Far too often, instead of the image of a person, the image of the foreigner as a "problem" is still created. Poverty and hunger etc. are in the foreground when it comes to dealing with other cultures. Often, not only the cultural diversity of people is faded out, but also the fact that rich and poor people live equally in Africa, Asia, South America as well as in North America and Europe. Therefore, Religious Education is first of all about understanding people as precious (fellow) human beings, as worthy creatures of God who, like all people, have wishes, dreams and worries.

Since life always happens from the other human being(s), it is also about an active perception of all moments in which people have to suffer (see also Metz, 2011). In particular, the reports of burning textile factories and poisoned plantation workers draw our attention to our interconnectedness with people we do not know, but with whom we are related through clothing, mobile phones and politics. The global perspective in Religious Education once again clearly points to the socio-political consequences and the responsibility that arise from the lived relationship with God. Christian faith always aims at interpreting and shaping society and the world.

Understanding Global (Citizenship) Education in Religious Education as diversity learning contributes to the maturity and cosmopolitan openness of young people; it enables young people to participate in shaping the world from the basis of Christian faith, and it promotes conviviality between people, cultures and religions, thus developing its humanizing influence.

Funding Open Access funding enabled and organized by Projekt DEAL.

Open Access This article is licensed under a Creative Commons Attribution 4.0 International License, which permits use, sharing, adaptation, distribution and reproduction in any medium or format, as long as you give appropriate credit to the original author(s) and the source, provide a link to the Creative Commons licence, and indicate if changes were made. The images or other third party material in this article are included in the article's Creative Commons licence, unless indicated otherwise in a credit line to the material. If material is not included in the article's Creative Commons licence and your intended use is not permitted by statutory regulation or exceeds the permitted use, you will need to obtain permission directly from the copyright holder. To view a copy of this licence, visit http://creativecommons.org/licenses/by/4.0/.

\section{References}

Abdullahi, S. A. (2015). Global Education. In J. Zajda (Ed.), Second international handbook on globalisation, education and policy research (pp. 793-806). Springer.

Akkari, A., \& Maleq, K. (2020). Global Citizenship Education: Recognizing diversity in a Global world. In A. Akkari \& K. Maleq (Eds.), Global Citizenship Education (pp. 3-13). Springer.

Albert, M., Hurrelmann, K. \& Quenze, G. (2019). Summary. In M. Albert, K. Hurrelmann \& G. Quenze (Eds.), Jugend 2019. Eine Generation meldet sich zu Wort (pp. 13-34). Beltz. https://www.shell.de/ about-us/shell-youth-study/_jcr_content/par/toptasks.stream/1570708594823/cc089c96f35209143fdf dcbead8365dc26f9a238/shell-youth-study-2019-summary-en.pdf. 
Beck, U. (1999). World risk society. Polity Press.

Benk, A. (2019). Globales Lernen als Kernaufgabe religiöser Bildung. In A. Benk (Ed.), Globales Lernen: Bildung unter dem Leitbild weltweiter Gerechtigkeit (pp. 213-224). Grünewald.

Bohl, T. (2013). Umgang mit Heterogenität im Unterricht. In T. Bohl \& S. Meissner (Eds.), Expertise gemeinschaftsschule: Forschungsergebnisse und handlungsempfehlungen für baden-württemberg (pp. 243-259). Beltz.

Congregation for Catholic Education. (2014). Educating today and tomorrow: A renewing passion. http:// www.vatican.va/roman_curia/congregations/ccatheduc/documents/rc_con_ccatheduc_doc_20140407_ educare-oggi-e-domani_en.html.

Francis. (2013). Apostolic Exhortation Evangelii Gaudium of the Holy Father Francis to the bishops, clergy, consecrated persons and the lay faithful on proclamation of the Gospel in today's world. http://www. vatican.va/content/francesco/en/apost_exhortations/documents/papa-francesco_esortazione-ap_20131 124_evangelii-gaudium.html.

Francis. (2015). Encyclical letter Laudato si' of the Holy Father Francis: On care for our common home. http://www.vatican.va/content/francesco/en/encyclicals/documents/papa-francesco_20150524_encic lica-laudato-si.html.

Francis. (2020). Fratelli Tutti: Encyclical Letter of the Holy Father Francis on Fraternity and Social Friendship. http://www.vatican.va/content/francesco/en/encyclicals/documents/papa-francesco_20201003_ enciclica-fratelli-tutti.html.

Gaus, R. (2014). Globales lernen im religionsunterricht als beitrag zur persönlichkeitsentwicklung. IRP Impulse, 12(1), 36-39.

Gaus, R. (2015). Plädoyer für eine globale perspektive: Globales und ökumenisches lernen im religionsunterricht. Notizblock, 27(58), 3-6.

Gaus, R. (2018). Globales Lernen im Religionsunterricht. In J. Sautermeister \& E. Zwick (Eds.), Religion und Bildung: Antipoden oder Weggefährten? Diskurse aus historischer, systematischer und praktischer Sicht (pp. 337-347). Schöningh.

German Advisory Council on Global Change [WBGU]. (2011). World in transition: A social contract for sustainability. WBGU. https://www.wbgu.de/fileadmin/user_upload/wbgu/publikationen/hauptgutac hten/hg2011/pdf/wbgu_jg2011_en.pdf.

Gruehn, S., \& Koinzer, T. (2019). Gesellschaftliche Funktionen privater katholischer Schulen: Programmatik und empirische Befunde. In J. Könemann \& D. Spiekermann (Eds.), Katholische Schulen: Herausgeforderte Identität (pp. 39-60). Schönigh.

Grümme, B. (2016). Human rights education and religious education: A catholic perspective. In M. L. Pirner, J. Lähnemann, \& H. Bielefeldt (Eds.), Interdisciplinary studies in human rights: Vol. 1 Human rights and religion in educational contexts (pp. 199-207). Springer.

Grümme, B. (2019). Religionspädagogische Denkformen: Eine kritische Revision im Kontext von Heterogenität. Herder.

Huckle, J., \& Wals, A. (2015). The UN decade of education for sustainable development: Business as usual in the end. Environmental Education Research, 21(3), 491-505. https://doi.org/10.1080/13504622. 2015.1011084

Kronauer, M. (2006). Exklusionals Kategorie einer kritischen Gesellschaftsanalyse: Vorschläge für eine anstehende Debatte. In H. Bude \& A. Willisch (Eds.), Das Problem der Exklusion: Ausgegrenzte, Entbehrliche, Überflüssige (pp. 27-45). Hamburger.

Lang-Wojtasik, G. (2011). Inklusion in die Weltgesellschaft durch Schule: Religiöse Orientierungen als Chance? In U. Kropač \& G. Langenhorst (Eds.), Religionsunterricht und der Bildungsauftrag der öffentlichen Schulen: Begründung und Perspektiven des Schulfaches Religionslehre (pp. 12-26). LUSA.

Lang-Wojtasik, G. (2018). Heterogenität und Inklusion als pädagogisch-didaktische Dauerbrenner: Reflexive Distanz über Differenz als Chance. In G. Lang-Wojtasik \& S. König (Eds.), Weingartner Dialog über Forschung: Vol. 2. Inklusion als gesellschaftliche, pädagogische und hochschulische Herausforderung (pp. 19-44). Klemm u. Oelschläger.

Luhmann, N. (2019). Schriften zur Organisation (E. Lukas, \& V. Tacke, Eds.) (Bd. 2: Theorie organisierter Sozialsysteme). Springer VS. https://doi.org/10.1007/978-3-658-23210-8

Maussen, M., \& Bader, V. (2014). Non-governmental religious schools in Europe: Institutional opportunities, associational freedoms, and contemporary challenges. Comparative Education, 51(1), 1-21. https://doi.org/10.1080/03050068.2014.935581

Metz, J. B. (2011). Weltprogramm des Christentums im Pluralismus der Religionen und Kulturen: Compassion. In J. B. Metz (Ed.), Memoria passionis. Ein provozierendes Gedächtnis in pluralistischer Gesellschaft (4th ed., pp. 158-178). Herder. 
Meyer, K. (2015, February 19). Fremdheit als didaktische Aufgabe. Das wissenschaftlich-religionspädagogische Lexikon (www.wirelex.de). https://doi.org/10.23768/wirelex.Fremdheit_als_didaktische_Aufga be. 100069

Noormann, H. (2012). Ökumenisches Lernen. In G. Lang-Wojtasik \& U. Klemm (Eds.), Handlexikon Globales Lernen (pp. 194-196). Klemm u Oelschläger.

Organisation for Economic Co-operation and Development. (2018). PISA Preparing our Youth for an inclusive and sustainable world. The OECD PISA global competence framework. OECD Publishing. https://www.oecd.org/pisa/Handbook-PISA-2018-Global-Competence.pdf.

Organisation for Economic Co-operation and Development. (2019). PISA 2018 Global Competence Framework. In: Organisation for Economic Co-operation and Development (Ed.), PISA 2018 Assessment and Analytical Framework (pp. 165-215). OECD Publishing. https://doi.org/10.1787/043fc3b0-en

Organisation for Economic Co-operation and Development. (2020). PISA 2018 results (volume VI): Are students ready to thrive in an interconnected world? OECD Publishing. https://doi.org/10.1787/d5f68 679-en

Pickel, G., \& Pickel, S. (2019). Der Flüchtling als Muslim und unerwünschter Mitbürger? In O. Hidalgo \& G. Pickel (Eds.), Politik und religion. Flucht und Migration in Europa: Neue Herausforderungen für Parteien, Kirchen und Religionsgemeinschaften (pp. 284-323). Springer.

Scheunpflug, A. (2012). Globales lernen und religiöse bildung. ZPT, 64(3), 221-230.

Schreiber, J.-R., \& Siege, H. (Eds.). (2016). Orientierungsrahmen für den Lernbereich Globale Entwicklung im Rahmen einer Bildung für nachhaltige Entwicklung: Ergebnis des gemeinsamen Projekts der Kultusministerkonferenz (KMK) und des Bundesministeriums für wirtschaftliche Zusammenarbeit und Entwicklung (BMZ). Cornelsen Verlag. https://www.globaleslernen.de/sites/default/files/files/linkelements/orientierungsrahmen_fuer_den_lernbereich_globale_entwicklung_barrierefrei.pdf.

Schweiker, W. (2012). Arbeitshilfe Religion inklusiv: Bd. 1: Basisband. Calwer Verlag.

Schweitzer, F. (2020). Fachliche Entwicklungen in der Religionspädagogik: Thematische und methodische Forschungsschwerpunkte in den letzten 30 Jahren. In B. Schröder \& T. Schlag (Eds.), Praktische Theologie und Religionspädagogik: Systematische, empirische und thematische Verhältnisbestimmungen (pp. 265-283). Evangelische Verlagsanstalt GmbH.

Siebenrock, R. A. (2009). Theologischer Kommentar zur Erklärung über die christliche Erziehung Gravisissimum educationis. In P. Hünermann \& B. J. Hilberath (Eds.), Herders Theologischer Kommentar zum zweiten Vatikanischen Konzil (pp. 551-590). Herder.

Trautmann, M., \& Wischer, B. (2011). Heterogenität in der Schule: Eine kritische Einführung. VS Verlag Für Sozialwissenschaften. https://doi.org/10.1007/978-3-531-92893-7

United Nations. (1948). Universal Declaration of Human Rights: (A/Res/3/217 (III)). United Nations. http:// www.un-documents.net/a3r217a.htm.

United Nations. (1992). Report of the United Nations Conference on Environment and Development: Annex II. AGENDA 21. Rio Declaration on Environment and Development. (Report No. A/conf.151/26/Rev. 1 (Vol. I)). United Nations. https://www.un.org/en/development/desa/population/migration/generalass embly/docs/globalcompact/A_CONF.151_26_Vol.I_Declaration.pdf.

United Nations. (2015). Transforming our world: The 2030 Agenda for Sustainable Development. (A/ RES/70/1). United Nations. http://www.un.org/ga/search/view_doc.asp?symbol=A/RES/70/1\& Lang=E.

United Nations Educational, Scientific and Cultural Organization. (2015). Global citizenship education: Topics and learning objectives. UNESCO. http://www.unesco.org/new/fileadmin/MULTIMEDIA/ FIELD/Beirut/pdf/GCEDTopicsandLearningObjectives_01.pdf.

United Nations Educational, Scientific and Cultural Organization. (2020). Education for Sustainable Development. A roadmap. UNESCO. https://unesdoc.unesco.org/ark:/48223/pf0000374802.locale=en.

Vatican Council, \& Paul VI. (1965, October 28). Gravissimum educationis: Declaration on Christian Education. Vatican City. http://www.vatican.va/archive/hist_councils/ii_vatican_council/documents/vat-ii_ decl_19651028_gravissimum-educationis_en.html.

Walgenbach, K. (2014). Heterogenität: Intersektionalität: Diversity in der erziehungswissenschaft. Budrich.

Weis, M., Reiss, K., Mang, J., Schiepe-Tiska, A., Diedrich, J., Roczen, N., \& Jude, N. (2020). Global competence in PISA 2018: Einstellungen von Fünfzehnjährigen in Deutschland zu globalen und interkulturellen Themen. Waxmann. https://doi.org/10.31244/9783830993001

World Council of Churches (WCC). (2018). Theology of the oikos [Special Issue]. The Ecumenical Review, 70(4), 597-807.

Yendell, A. (2017). Young people and religious diversity: A European perspective, with particular reference to Germany. In E. Arweck (Ed.), Young people's attitudes to religious diversity (pp. 275-288). Routledge. 
Publisher's Note Springer Nature remains neutral with regard to jurisdictional claims in published maps and institutional affiliations. 